\title{
PELAKSANAAN CORPORATE SOCIAL RESPONSIBILITY PT. TIRTA INVESTAMA SUBANG DALAM MEMBERDAYAKAN EKONOMI MASYARAKAT DESA PASANGGRAHAN KECAMATAN KASOMALANG KABUPATEN SUBANG
}

\author{
TM. Marwanti ${ }^{1}$; Yani Sumyani ${ }^{2}$; Rany Juliani ${ }^{3}$; Andry Widiyanto ${ }^{4}$
}

${ }^{1}$ Dosen Politeknik Kesejahteraan Sosial Bandung; ${ }^{2}$ Mahasiswa Politeknik Kesejahteraan Sosial Bandung; ${ }^{3}$ Sustainable Development PT. Tirta Investama Subang;

4Pemberdaya Human Initiative Jabar email:marwanti.wanti@gmail.com';yanisumyani98@gmail.com²; rany.juliani@danone.com ${ }^{3}$;andrywywy@gmail.com ${ }^{4}$

Paper Accepted: 15 September 2021 Paper Reviewed: 16-23 September 2021 Paper Edited: 24-30 September 2021 Paper Approved: 01 Oktober 2021

\begin{abstract}
ABSTRAK
Penelitian ini bertujuan untuk mendapatkan gambaran pelaksanaan tanggung jawab sosial perusahaan PT. Tirta Investama Subang dalam program pemberdayaan ekonomi masyarakat yang dilaksanakan di Desa Pasanggrahan Kecamatan Kasomalang Kabupaten Subang. Penelitian ini menggunakan pendekatan kualitatif dengan metode deskriptif. Sumber data yang digunakan adalah sumber data primer dan sumber data sekunder. Teknik pengumpulan data yang digunakan yaitu wawancara mendalam, observasi langsung dan studi dokumentasi. Adapun teknik pemeriksaan keabsahan data yang digunakan adalah uji kredibilitas, pengujian transferability dan pengujian dependability. Hasil penelitian menunjukkan bahwa PT. Tirta Investama Subang bersama Human Initiative Jabar sudah melaksanakan tahapan pelaksanaan CSR nya dengan baik yang terdiri dari 1) Tahap perencanaan meliputi Awareness Building, CSR Assessment dan CSR Manual Building. 2) Tahap pelaksanaan meliputi sosialisasi untuk memperkenalkan kepada komponen perusahaan mengenai pelaksanaan CSR, pelaksanaan program dan proses internalisasi CSR dalam seluruh proses bisnis perusahaan melalui program "Aqua Lestari", dan 3) Tahap Evaluasi Lapangan meliputi proses monitoring dan evaluasi, pelaporan dan audit.
\end{abstract}

Kata Kunci: Pelaksanaan CSR, Pemberdayaan Ekonomi

\section{PENDAHULUAN}

Pada tatanan globalisasi sekarang ini arus bisnis perusahaan semakin mengemuka, mengingat arus derasnya perekonomian di dunia yang tiada hentinya di tatanan global meskipun dalam situasi yang sangat terbatas disebabkan adanya wabah covid-19 yang menyebabkan laju pertumbuhan ekonomi sedikit tersendat. Meskipun demikian tanggung jawab sebuah perusahaan tidak terlepas dengan adanya tanggung jawab sosial dan moral 
terhadap lingkungan sekitar dimana perusahaan tersebut beroperasi. Dan hal tersebut sudah diatur dalam UU Perseroan Terbatas Republik Indonesia Nomor 40 Tahun 2007 Pasal 74 Ayat 1 tentang Tanggung Jawab Sosial dan Lingkungan. Secara sederhana, Corporate Social Responsiility diartikan sebagai komitmen perusahaan atau dunia industri untuk berkontribusi dalam pengembangan ekonomi yang berkelanjutan dengan memperhatikan tanggung jawab sosial perusahaan dan menitikberatkan pada keseimbangan antara perhatian terhadap aspek ekonomis, sosial dan lingkungan (Hendrik Budi Untung, 2008). Usaha ke arah tersebut dilakukan dengan berbagai cara yang berbeda antara satu perusahaan dengan perusahaan lainnya. PT. Tirta Investama Subang merupakan salah satu perusahaan yang melaksanakan program Corporate Social Responsibility nya melalui Program Pengembangan Ekonomi Masyarakat atau biasa disebut ECODEV. Program ini merupakan program yang berkelanjutan dan sebagai kepedulian pihak perusahaan dalam merespon masalah dan kebutuhan masyarakat Desa Pasanggrahan yang terjebak dengan bank keliling (Banke / Bank Emok). Dalam merespon masalah tersebut PT. Tirta Investama Subang melakukan pendampingan kepada masyarakat Desa Pasanggrahan khususnya kepada lembaga, pengurus dan anggota Koperasi Pasgajaya Desa Pasanggrahan sebagai salah satu potensi finansial masyarakat dan sebagai sarana peminjaman serta lembaga yang mengakomodir produk para pelaku Usaha Mikro Kecil Menengah (UMKM). Hasil pendampingan yang dilakukan oleh PT. Tirta Investama Subang memberikan kontribusi yang cukup besar terhadap peningkatan ekonomi masyarakat Desa Pasanggrahan yang lebih memadai dan berhasil mengembangkan 38 pelaku UMKM yang tersertifikasi legal halal, memiliki SPKP (Surat Penyuluhan Keamanan Pangan) dari Dinas Kesehatan Kabupaten Subang serta memiliki rata-rata pendapatan omset usaha pelaku UMKM di Tahun 2020 sebesar Rp 4.570.000. Selain itu, setelah adanya program pengembangan ekonomi masyarakat, koperasi yang berperan sebagai lokomotif yang mengkomodir semua produk UMKM dan sekaligus sebagai pemasar dengan cara kemitraan bisnis multi pihak (offline) mengalami peningkatan nasabah yaitu tercapai 285 nasabah. Keberhasilankeberhasilan yang telah dicapai oleh PT. Tirta Investama Subang menjadi alasan dan ketertarikan bagi peneliti untuk melakukan penelitian lebih dalam mengenai "Pelaksanaan Corporate Social Responsibility PT. Tirta Investama Subang Dalam Memberdayakan Ekonomi Masyarakat Di Desa Pasanggarahan Kecamatan Kasomalang Kabupaten Subang"

\section{METODE PENELITIAN}

Kegiatan penelitian ini dilaksanakan selama 8 bulan yaitu dari bulan Desember 2020 sampai Juli 2021 meliputi tahap persiapan, pelaksanaan, analisis dan penyusunan. Pada tahap persiapan, peneliti melakukan studi literatur, penetuan topik dan pengajuan judul, penyusunan proposal, seminar proposal, penyusunan instrument penelitian dan melakukan penjajakan. Pada tahap pelaksanaan, peneliti melakukan pengumpulan data dengan menggunakan metode kualitatif yang bertujuan untuk mengetahui dan memahami proses pelaksanaan CSR PT. Tirta Investama dalam memberdayakan ekonomi masyarakat Desa Pasanggrahan. Sumber data yang digunakan yaitu sumber data primer dan sumber data sekunder. Sumber data primer diperoleh melalui proses wawancara mendalam dan observasi langsung sedangkan sumber data sekunder diperoleh melalui studi dokumentasi. Informan dalam penelitian ini dilaksanakan secara purposive berdasarkan tujuan dari pengumpulan informasi kepada 5 informan yang terdiri dari pemberdaya Human Initiative Jabar dan penerima manfaat dalam program pemberdayaan ekonomi. Validasi data dilakukan melalui uji kredibilitas, pengujian transferability dan pengujian dependability. Pada tahap analisis data, peneliti melakukan pengolahan data yaitu melakukan analisis terhadap jawaban dari informan penelitian melalui reduksi data (data reduction), penyajian data (data display) 
dan penarikan kesimpulan (conclusion drawing/verification). Pada tahap penyusunan, peneliti menyusun dan melakukan bimbingan penulisan skripsi serta seminar penelitian.

\section{HASIL DAN PEMBAHASAN}

\section{Gambaran Umum Lokasi Penelitian PT. Tirta Investama Subang}

PT. Tirta Investama Subang berdiri pada tahun 1997 dan mulai beroperasi secara resmi pada tanggal 8 Desember 1997. PT. Tirta Investama Subang atau yang lebih dikenal oleh masyarakat luas dengan nama AQUA ini berlokasi di Jl. Kampung Salam, Desa Darmaga, Kecamatan Cisalak, Kabupaten Subang ini memiliki luas lahan 13,00 hektar (ha). Secara topografi, area kerja PT. Tirta Investama Subang merupakan area yang terletak di bagian selatan Kabupaten Subang dan berada di lembah antara perbukitan di bagian utara dan selatan dengan elevasi antara $20-600$ mdpl. PT. Tirta Investama Subang memiliki jumlah karyawan sebanyak 439 orang yang terdiri dari karyawan laki-laki sebanyak 417 orang yang banyak ditempatkan di bagian operasional produksi dan karyawan perempuan sebanyak 22 orang yang banyak ditempatkan di bagian admin produksi dan tim support (office). Karyawan tersebut berasal dari Kabupaten Subang sebanyak $99 \%$ dan luar Kabupaten Subang sebanyak $1 \%$ sehingga lebih memprioritaskan tenaga di daerah sekitar operasional perusahaan. Dalam produksinya, PT. Tirta Investama Subang memproduksi Air Mineral Dalam Kemasan (AMDK) yang berukuran galon (19 liter) dan botol $600 \mathrm{ml}$ dengan standar internasional, sehingga melalui tahapan yang ketat dalam pengelolaannya yang bertujuan menjaga kualitas air sampai ke tangan konsumen.

\section{Desa Pasanggrahan}

Desa Pasanggrahan merupakan salah satu desa yang terletak di Kecamatan Kasomalang Kabupaten Subang. Desa Pasanggrahan ini menjadi salah satu lokasi operasional program CSR AQUA Subang yang berbatasan dengan Desa Sindangsari Kecamatan Kasomalang di bagian utara. Berbatasan dengan Desa Cupunagara / Cibitung Kecamatan Cisalak / Ciater di bagian selatan. Berbatasan dengan Desa Sanca di bagian barat dan berbatasan dengan Desa Darmaga di bagian timur. Luas wilayah Desa Pasanggrahan adalah 551,13 hektar (ha) yang sebagian besar lahan digunakan oleh masyarakat Desa Pasanggrahan sebagai lahan pesawahan yaitu seluas 270,10 hektar (ha) sehingga komoditas unggulan dari Desa Pasanggrahan yaitu padi. Lahan pesawahan hampir ada di setiap RW yang ada di Desa Pasanggrahan yaitu terdapat di 9 RW dari total $10 \mathrm{RW}$ yang ada di Desa Pasanggrahan.

\section{Koperasi Pasgajaya Abadi Desa Pasanggrahan}

Koperasi Pasgajaya Abadi merupakan lembaga dampingan dalam program pemberdayaan ekonomi yang dilakukan oleh PT. Tirta Investama Subang bersama Human Initiative Jabar. Pada awalnya, Koperasi Pasgajaya didirikan atas keprihatinan Ketua PKK Desa Pasanggrahan yang juga merupakan istri dari Kepala Desa Pasanggrahan yaitu Ibu Aan Komalasari karena maraknya warga Desa Pasanggrahan yang terjerat pada praktik riba (peminjaman pada Bank Keliling). Berawal dari obrolan mengenai hal tersebut dengan pihak AQUA, Ibu Aan Komalasari disarankan untuk membuat Lembaga Ekonomi Desa (LED). Pada tanggal 12 September 2013 merupakan awal pembentukan LED Pasgajaya (sebelum menjadi koperasi di tahun 2016) dengan jumlah anggota 20 orang pada waktu itu, setelah itu diadakan pemilihan pengurus dan terpilih ibu Aan Komalasari sebagai ketua LED Pasgajaya. Koperasi Pasgajaya Abadi ini beralamatkan di Jalan Raya Pasanggrahan RT 22 / RW 07 Desa Pasanggrahan. Dana awal yang dimiliki Koperasi Pasgajaya sebesar Rp.500.000 yang merupakan bantuan dana dari UP2K PKK. Hingga pada bulan November 2012, Koperasi Pasgajaya mendapatkan bantuan stimulant berupa dana sebesar Rp.10.000.000 dari pihak PT. Tirta Investama Subang. Mengingat tujuan awal 
dibentuknya Koperasi Pasgajaya adalah supaya menjadi solusi agar masyarakat Desa Pasanggrahan tidak terjerat oleh Bank Keliling, sehingga pengurus berdasarkan kesepakatan dan kesanggupan dari anggota menetapkan simpanan pokok yang tidak memberatkan yakni sebesar Rp.5.000. Anggota Koperasi Pasgajaya hingga saat ini berjumlah 285 orang yang tersebar diseluruh wilayah Desa Pasanggrahan dengan dua unit usaha yaitu Simpan Pinjam dan Warung Koperasi.

\section{Tahapan Pelaksanaan Corporate Social Responsibility PT. Tirta Investama Subang Dalam Memberdayakan Ekonomi Masyarakat Desa \\ Pasanggrahan \\ Dalam melaksanakan program} pemberdayaan ekonomi masyarakat, PT. Tirta Investama Subang bekerja sama atau menunjuk Human Initiavtive Jabar sebagai penanggung jawab pelaksana teknis atau penanggung jawab lapangan yang membentuk sebuah tim pelaksana program dengan jumlah orang dan bagian yang diperlukan. Berdasarkan estimasi luasan area, jumlah kelompok pelaku usaha produktif yang dilakukan, maka program ini melibatkan 3 (tiga) orang inti dengan pembagian: 1 (satu) orang Project Manager dan 2 orang pendamping lapangan/fasilitator. Sehingga yang mendampingi masyarakat secara langsung atau melakukan proses pendampingan kepada masyarakat adalah pihak Human Initiative Jabar.

Berdasarkan hasil penelitian dapat disimpulkan bahwa PT. Tirta Investama Subang sudah melaksanakan tahapan pelaksanaan CSR nya dengan baik. Pertama, tahap perencanaan yang dilakukan PT. Tirta Investama Subang sudah sesuai dengan aspek-aspek yang ada dalam teori. Menurut Yusuf Wibisono (2007:121-124) pada tahap perencanaan memiliki tiga langkah utama yaitu Awareness Building, CSR Assessment dan CSR Manual Building". Langkah pertama dalam tahap perencanaan yaitu melakukan Awareness Building yaitu langkah awal untuk membangun dan menumbuhkan kesadaran akan pentingnya tanggung jawab sosial bagi perusahaan (Yusuf Wibisono (2007:121-124)). PT. Tirta Investama Subang merupakan perusahaan yang memiliki komitmen tinggi untuk menjalankan bisnis dengan mengedepankan keseimbangan antara keberhasilan ekonomi dan kemajuan sosial. Hal ini juga sejalan dengan pemikiran pendiri AQUA, yaitu Bapak Tirto Utomo yang berprinsip bahwa bisnis harus berkontribusi pada pengembangan sosial masyarakat. Sehingga pihak perusahaan memiliki kesadaran yang tinggi untuk menjalankan tanggung jawab sosial perusahaan melalui program nya yaitu "Aqua Lestari" yang sudah berjalan sejak tahun 2006. Berdasarkan uraian diatas dapat kita ketahui bahwa salah satu indikator kinerja kunci pelaksanaan CSR PT. Tirta Investama Subang yaitu faktor leadership (kepemimpinan) yang baik. Hal ini sejalan dengan pendapat Dwi Kartini (2009:54) yang menyampaikan bahwa "Program CSR dapat dikatakan berhasil jika mendapatkan dukungan dari top management perusahaan, terdapat kesadaran filantropik dari pimpinan yang menjadi dasar pelaksanaan program". Selain itu, Awareness Building ini tidak hanya dilakukan di lingkungan perusahaan saja, tetapi juga dilakukan di lingkungan masyarakat melalui kegiatan Sosialisasi Data Rencana Kerja, pada intinya kegiatan ini merupakan proses pemaparan laporan hasil social mapping kepada masyarakat, namun kegiatan ini juga merupakan salah satu upaya yang dilakukan oleh pihak perusahaan untuk membangun kesadaran masyarakat tentang pentingnya program CSR yang dilakukan oleh pihak perusahaan sehingga antara perusahaan, Human Initiative Jabar dan masyarakat bersinergi dalam menjalankan program pemberdayaan ekonomi yang dilakukan.

Langkah kedua pada tahap perencanaan yaitu melakukan CSR Assessment. Menurut Yusuf Wibisono (2007:121-124) CSR Assessment merupakan "Upaya untuk memetakan kondisi perusahaan dan mengidentifikasi aspek yang perlu mendapatkan prioritas". CSR Assessment yang dilakukan oleh PT. Tirta Investama Subang bersama Human Initiative Jabar dilaksanakan melalui 
kegiatan Social Mapping yaitu proses asesmen atau penggalian informasi secara luas terkait masyarakat terutama pemetaan masalah, pemetaan potensi, pemetaan kebutuhan dan rekomendasi program yang sesuai dengan pioritas kebutuhan masyarakat. Social mapping ini dilakukan setiap lima tahun sekali dan dilakukan updating setiap satu tahun sekali. Dalam melaksanakan social mapping ini, pihak perusahaan bersama Human Initiative Jabar melibataktifkan masyarakat Desa Pasanggrahan dari seluruh kalangan sehingga memberikan ruang bagi masyarakat dalam pengambilan keputusan dan perencanaan program yang akan dilaksanakan agar sesuai dengan kebutuhan masyarakat dan tepat sasaran. Hal tersebut sejalan dengan yang disampaikan oleh Dwi Kartini (2009:54) bahwa perencanaan yang melibatkan multi-stakeholder pada setiap siklus pelaksanaan program, terdapat kesadaran untuk memperhatikan aspek-aspek lokalitas (local wisdom), pada saat perencanaan ada kontribusi, pemahaman dan penerimaan terhadap budaya-budaya lokal yang ada maka hal tersebut menjadi salah satu indikator kinerja kunci keberhasilan dalam pelaksanaan CSR.

Langkah terakhir pada tahap perencanaan yaitu melakukan CSR Manual Building. Menurut Yusuf Wibisono (2007:121-124) CSR Manual Building merupakan "Tahapan dimana setelah diketahui kebutuhan-kebutuhan, maka dibuatlah pedoman pelaksanaan tanggungjawab sosial perusahaan di sebuah perusahaan". Berdasarkan hasil analisis data social mapping, Human Initiative Jabar sebagai pelaksana program dan penanggung jawab lapangan memahami apa yang menjadi masalah dan kebutuhan masyarakat. Namun, untuk memaksimalkan proses CSR Manual Building nya, pendamping lapangan tidak hanya mempelajari dari laporan social mapping saja, tapi juga mempelajari dan mengkaji evaluasi dari program-program yang sudah dijalankan atau melakukan diskusi dengan fasilitator sebelumnya. Hal ini dilakukan karena pada setiap tahunnya mengalami pergantian pendamping lapangan sesuai kontrak kerja selama dua tahun atau sesuai kesepakatan. Setelah diketahui apa yang menjadi masalah dan kebutuhan masyarakat, maka dibuatlah time line rencana program yang akan dilaksanakan selama satu tahun ke depan di Desa Pasanggrahan oleh Human Initiative Jabar yang kemudian diajukan dan disetujui oleh pihak perusahaan sekaligus proses pencairan dana CSR untuk program pemberdayaan ekonomi yang akan dilaksanakan. Rencana program yang akan dilaksanakan tentunya sesuai dengan Standar Operasional Prosedur (SOP) yang telah disepakati oleh komite perusahaan dan Human Initiative Jabar yang mengacu pada indikator yang ingin dicapai sesuai dari hasil social mapping. 


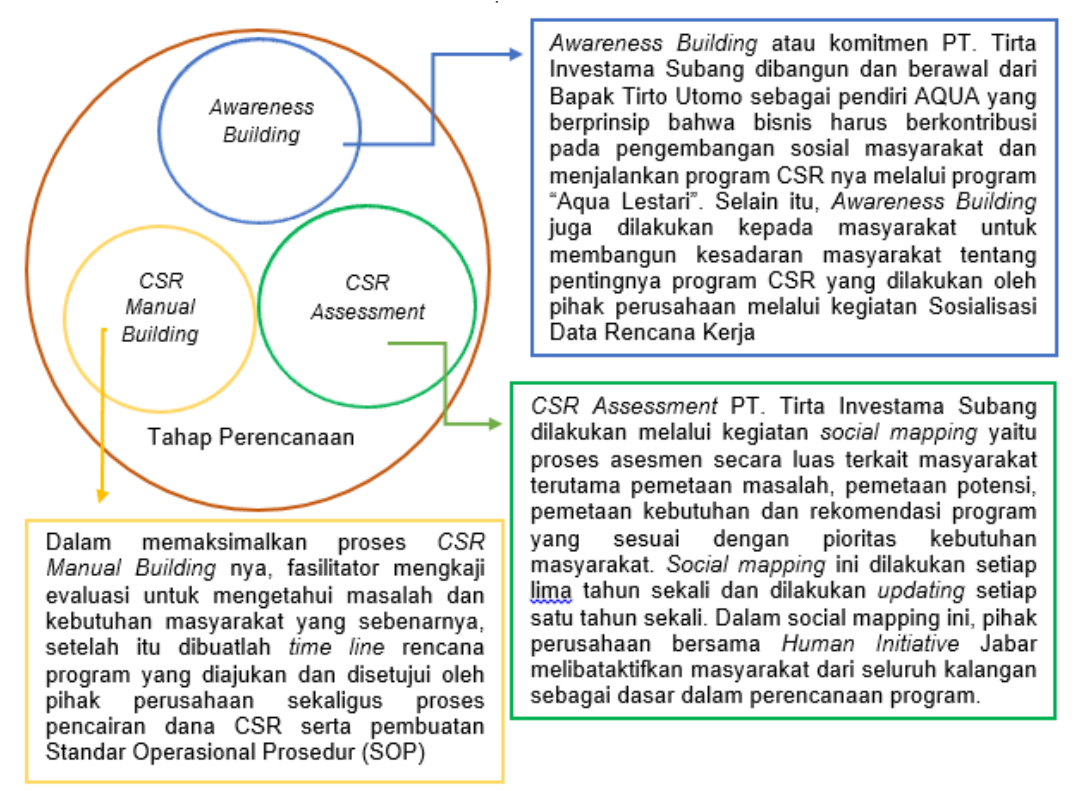

Gambar 1. Tahap Perencanaan Program CSR

Tahap kedua dalam pelaksanaan CSR yaitu tahap pelaksanaan. Tahap pelaksanaan yang dilakukan PT. Tirta Investama Subang sudah sesuai dengan aspek-aspek yang ada dalam teori. Menurut Yusuf Wibisono (2007:121-124) "Tahap pelaksanaan ini terdiri dari tiga langkah utama, yaitu sosialisasi untuk memperkenalkan kepada komponen perusahaan mengenai pelaksanaan tanggung jawab sosial perusahaan. Kedua adalah pelaksanaan program tanggung jawab sosial perusahaan yang telah disusun. Selanjutnya adalah internalisasi yang mencakup upaya-upaya untuk memperkenalkan tanggung jawab sosial perusahaan di dalam seluruh proses bisnis perusahaan". Berdasarkan hasil penelitian, langkah pertema yang dilakukan PT. Tirta Investama Subang pada tahap pelaksanaan yaitu melakukan proses sosialisasi terkait pelaksanaan dan pentingnya tanggung jawab sosial perusahaan yang dilakukan oleh AQUA Group yang menaungi PT. Tirta Investama Subang melalui program "Aqua Lestari". Program Aqua Lestari ini menjadi komitmen dan kewajiban AQUA Group beserta perusahaan yang menjadi cabangnya termasuk PT. Tirta Investama
Subang yang harus dilaksanakan serta terinternalisasi dalam seluruh proses bisnis perusahaan yang dilakukan melalui pelaksanaan berbagai program CSR dalam berbagai bidang. Kemudian Menurut Yusuf Wibisono (2007:121-124) pada tahap pelaksanaan CSR dilakukan "Pelaksanaan program tanggung jawab sosial perusahaan yang telah disusun". Hal ini sejalan dengan yang dilakukan oleh PT. Tirta Investama Subang bersama Human Initiative Jabar yaitu melaksanakan program yang sudah direncanakan dan disepakati bersama masyarakat seperti memberikan edukasi dan motivasi kepada masyarakat, melaksanakan proses advokasi dengan lembaga dan dinas setempat sesuai kebutuhan masyarakat, dan membangun kerjasama dengan para stakeholder dan orang yang expert dalam bidangnya untuk memberikan kegiatan workshop sesuai rencana kerja yang telah disusun bersama masyarakat. Berdasarkan uraian tersebut dapat kita ketahui bahwa salah satu indikator kinerja kunci keberhasilan pelaksanaan CSR yang dilakukan oleh PT. Tirta Investama Subang bersama Human Initiative Jabar yaitu adanya pelibatan stakeholder (stakeholder mangement). Hal ini 
sejalan dengan yang disampaikan oleh Dwi Kartini (2009:54) yang mengatakan bahwa yang menjadi salah satu kinerja kunci keberhasilan pelaksanaan CSR yaitu aspek pelibatan stakeholder (stakeholder mangement) yaitu "Mekanisme koordinasi reguler dengan stakeholders utamanya masyarakat, terdapat mekanisme yang menjamin partisipasi masyarakat untuk dapat terlibat dalam siklus proyek".

Sosialisasi terkait pelaksanaan dan
pentingnya tanggung jawab sosial
perusahaan dilakukan oleh AQUA
Group yang menaungi PT. Tirta
Investama Subang melalui program
"Aqua Lestari"
PT. Tirta Investama Subang bersama
Human Initiative Jabar melaksanakan
program yang sudah direncanakan dan
disepakati bersama masyarakat seperti
memberikan edukasi, motivasi,
melakukan proses advokasi dan
membangun kerjasama dengan
stakeholders dalam melaksanakan
kegiatan pelatihan / workshop sesuai
rencana kerja yang telah disusun
bersama masyarakat.

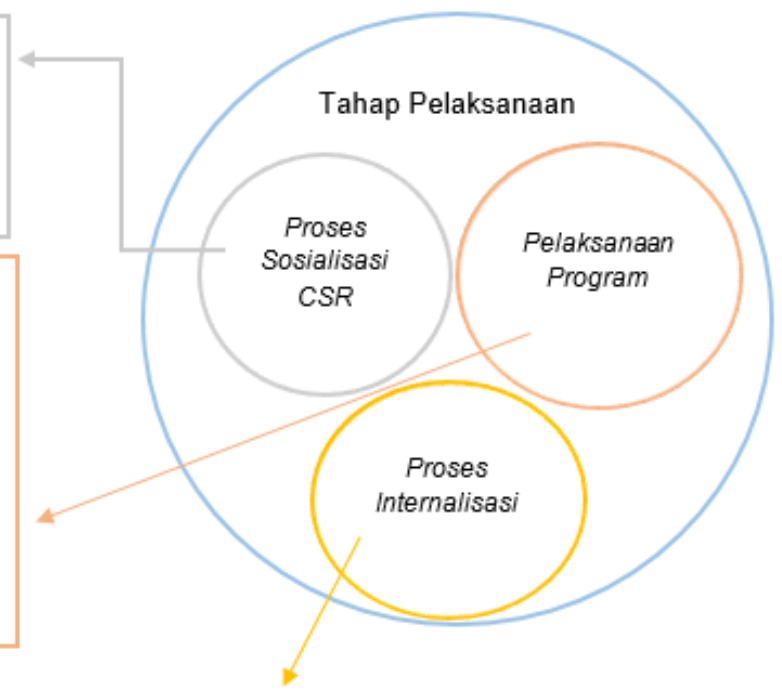

Proses internalisasi CSR dilakukan oleh PT. Tirta Investama Subang melalui program Aqua Lestari yang menjadi komitmen dan kewajiban AQUA Group beserta perusahaan yang menjadi cabangnya termasuk PT. Tirta Investama Subang dalam seluruh proses bisnis perusahaan yang dilakukan melalui pelaksanaan berbagai program CSR dalam berbagai bidang.

\section{Gambar 2. Tahap Pelaksanaan Program CSR}

Tahap selanjutnya yang dilakukan dalam pelaksanaan CSR yaitu tahap evaluasi dan tahap pelaporan. Menurut Yusuf Wibisono (2007:121-124) "Tahap evaluasi merupakan tahapan yang dilakukan secara berkala untuk menilai tingkat keberhasilan tanggung jawab sosial perusahaan. Tahap evaluasi ini perlu dilakukan secara konsisten untuk mengukur sejauh mana keefektivan program tanggung jawab sosial perusahaan yang sudah dilaksanakan. Evaluasi juga bisa dilakukan dengan meminta pihak independen untuk melakukan audit implementasi atas praktik tanggungjawab sosial perusahaan yang telah dilakukan". Sejalan dengan uraian teori diatas bahwa PT. Tirta Investama Subang sudah melaksanakan tahap evaluasi dengan baik sesuai dengan aspek-aspek tahap evaluasi yang ada dalam kajian pustaka. Yang mana dalam melaksanakan program CSR nya,
PT. Tirta Investama Subang juga melaksanakan tahap evaluasi lapangan. Dimana tahap evaluasi lapangan ini meliputi proses monitoring dan evaluasi, proses pelaporan dan audit. Evaluasi lapangan dilakukan secara berkala dan sesuai kesepakatan komite program antara pihak perusahaan dengan Human Initiative Jabar untuk memantau perkembangan atau capaian pelaksanaan program sesuai indikator yang telah ditentukan. PT. Tirta Investama Subang melakukan proses monitoring dan evaluasi. Dalam kegiatan ini Human Initiative Jabar melakukan proses monitoring dan evaluasi bersama masyarakat pada saat proses pendampingan sehingga memantau secara langsung kegiatan yang dilaksanakan di lapangan. Proses pendampingan ini juga memaksimalkan pelaksanaan program yang dilaksanakan di masyarakat, karena dengan adanya pendampingan ini, 
masyarakat dengan mudah mengkomunikasikan pencapain dan kendala yang dihadapi di lapangan kepada pendamping lapangan. Kemudian hasil monitoring dan evaluasi bersama masyarakat ini juga nantinya disampaikan secara tertulis dan reguler dan dipresentasikan dalam pertemuan antara PT. Tirta Investama Subang dengan Human Initiative selaku penanggung jawab lapangan baik secara langsung maupun tidak langsung. Kedua, pada tahap evaluasi lapangan juga terdapat proses pelaporan. Menurut Yusuf Wibisono (2007:121-124) tahap pelaporan yaitu "Bentuk transparansi kepada stakeholders terhadap pelaksanaan tanggungjawab sosial perusahaan. Pelaporan dilakukan dalam rangka membangun sistem informasi untuk keperluan proses pengambilan keputusan maupun keperluan keterbukaan informasi material dan relevan mengenai perusahaan". Berdasarkan hasil penelitian, proses pelaporan yang dilakukan dalam

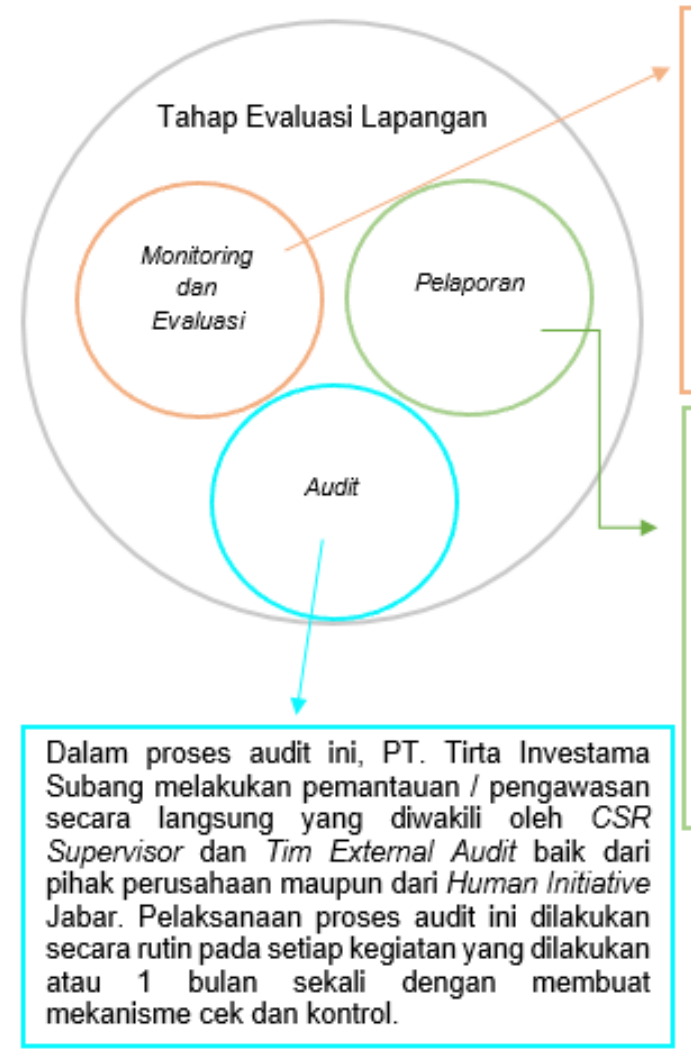

program pemberdayaan ekonomi ini disampaikan sesuai dengan tahap dan jadwal program lengkap dengan perkembangan intervensi sosial yang dilakukan. Dalam proses pelaporan ini, pihak perusahaan menerima laporan dari Human Initiative Jabar berupa laporan harian, laporan kegiatan, laporan bulanan dan laporan tahunan sebagai dasar dan sumber informasi dalam pengambilan keputusan bagi pemilik kebijakan perusahaan. Proses akhir yang dilaksanakan pada tahap evaluasi lapangan yaitu proses audit. Dalam proses audit ini, PT. Tirta Investama Subang melakukan pengawasan secara langsung yang diwakili oleh CSR Supervisor dan Tim External Audit baik dari pihak perusahaan maupun dari Human Initiative Jabar. Pelaksanaan proses audit ini dilakukan secara rutin pada setiap kegiatan yang dilakukan atau 1 bulan sekali dengan membuat mekanisme cek dan kontrol.

Fasilitator melakukan proses monitoring dan evaluasi kepada masyarakat pada saat proses pendampingan kemudian hasil monitoring dan evaluasi bersama masyarakat disampaikan dan dievaluasi bersama Project Manager Human Initiative Jabar yang nantinya disampaikan secara tertulis dan reguler dan dipresentasikan dalam pertemuan antara PT. Tirta Investama Subang dengan Human Initiative Jabar baik secara langsung ataupun tidak langsung.

Proses pelaporan yang dilakukan dalam program pemberdayaan ekonomi ini disampaikan sesuai dengan tahap dan jadwal program lengkap dengan perkembangan intervensi sosial yang dilakukan. Dalam proses pelaporan ini, pihak perusahaan menerima laporan dari Human Initiative Jabar berupa laporan harian, laporan kegiatan, laporan bulanan dan laporan tahunan sebagai dasar dan sumber informasi dalam pengambilan keputusan bagi pemilik kebijakan perusahaan.

Gambar 3. Tahap Evaluasi Program CSR 


\section{Faktor yang Mempengaruhi Keberhasilan Pelaksanaan Corporate Social Responsibility PT. Tirta Investama Subang Dalam Memberdayakan Ekonomi Masyarakat Desa Pasanggrahan}

Dalam penelitian ini juga diketahui bahwa faktor keberhasilan pelaksanaan CSR yang dilakukan oleh PT. Tirta Investama Subang yaitu adanya proses komunikasi yang baik. Hal ini sejalan dengan yang disampaikan oleh Solichin Abdul Wahab dalam M. Fitrah Wardiman (2015:16) yang mengatakan bahwa "Komunikasi merupakan salah satu faktor yang mempengaruhi keberhasilan pelaksanaan CSR apabila proses komunikasi ini disampaikan secara jelas bagi para pelaksana. Hal ini menyangkut proses penyampaian informasi, kejelasan informasi, dan konsistensi informasi yang disampaikan". Dalam melaksanakan program pemberdayaan ekonomi ini, pihak perusahaan dan Human Initiative Jabar mampu membangun komunikasi dengan baik. Dimana pendamping lapangan memiliki kemampuan untuk menyampaikan informasi dengan baik terkait pelaksanaan program yang akan dijalankan kepada seluruh pihak yang terlibat. Bahkan dalam setiap tahapan yang dilakukan, perusahaan bersama Human Initiative Jabar selalu melibatkan secara aktif masyarakat sehingga masyarakat merasa diakui dan berperan serta dalam proses pemberdayaan yang dilakukan. Selain itu, pendamping lapangan juga mampu memberikan kejelasan informasi dan konsisten dalam mengkomunikasikan proses di lapangan kepada pihak perusahaan. Kemudian pendamping lapangan juga mampu membangun komunikasi yang baik dengan masyarakat pada saat melakukan proses pendampingan sehingga masyarakat dengan mudah mengkomunikasikan kendala atau hambatan serta pencapaian kepada fasilitator dan terbangun kepercayaan dari setiap pihak yang dilibatkan.

Faktor lain yang mempengaruhi keberhasilan pelaksanaan CSR yang dilakukan oleh PT. Tirta Investama
Subang yaitu faktor disposisi yaitu komitmen pelaksana program khususnya bagi mereka yang menjadi implementer dari suatu program yang telah direncanakan guna mencapai tujuan yang ditetapkan" (Solichin Abdul Wahab dalam M. Fitrah Wardiman (2015:16)). Berdasarkan hasil penelitian pihak yang terlibat dalam program pemberdayaan ekonomi memiliki komitmen yang tinggi dalam mencapai tujuan program yang dilaksanakan. Pertama, pihak perusahaan memiliki komitmen untuk menjalankan bisnis dengan mengedepankan keseimbangan antara keberhasilan ekonomi dan kemajuan sosial. Kedua, pendamping lapangan dalam program pemberdayaan ekonomi juga memiliki komitmen dan semangat yang tinggi dalam menjalankan prosesnya di lapangan sehingga masyarakat sangat terbuka dan sangat dekat dengan fasilitator. Ketiga, komitmen ini juga dimiliki oleh masyarakat Desa Pasanggrahan. Program yang dilakukan oleh PT. Tirta Investama Subang merupakan program yang berkelanjutan (sustainable) dan memberikan dampak yang positif bagi masyarakat sehingga masyarakat selalu mendukung program yang dilaksanakan oleh CSR AQUA dan ikut berpartisipasi dalam kegiatan yang dilaksanakan meskipun belum maksimal. Selain itu, pengurus dan anggota Koperasi Pasgajaya khsususnya UMKM juga sangat terbuka dan memiliki sense of belonging terhadap program pemberdayaan ekonomi yang sudah dilakukan sehingga beberapa program yang sudah dilaksanakan juga mampu diterapkan atau diimplementasikan oleh pengurus atau anggota Koperasi Pasgajaya. Hal ini sejalan dengan yang disampaikan oleh Dwi Kartini (2009:54) yang mengatakan bahwa salah satu kinerja kunci keberhasilan yaitu pelaksanaan CSR dilakukan secara berlanjut (sustainability).

Struktur birokrasi juga mempengaruhi keberhasilan pelaksanaan CSR yang dilakukan oleh PT. Tirta Investama Subang. Hal ini sejalan dengan pernyataan Solichin Abdul Wahab dalam M. Fitrah Wardiman (2015:16) yang mengatakan bahwa "Struktur birokrasi merupakan salah satu faktor yang mempengaruhi 
keberhasilan. Struktur birokrasi ini yaitu SOP (Standar Operating Procedures) yang mengatur tata aliran dalam pelaksanaan program". Berdasarkan hasil penelitian, kebijakan dan program "Aqua Lestari" yang diselenggarakan oleh PT. Tirta Investama Subang merupakan landasan dan pendukung dalam program pemberdayaan ekonomi yang dilakukan di Desa Pasanggrahan. Sehingga dengan adanya program tersebut, perusahaan juga mendukung sumber keuangan/dana untuk pelaksanaan program pemberdayaan ekonomi yang dilakukan di Desa Pasanggrahan. Selain itu, dalam pelaksanaan program pemberdayaan ekonomi masyarakat di Desa Pasanggrahan juga terdapat pembagian peran dan tugas secara jelas yang disepakati oleh pihak perusahaan bersama Human Initiative Jabar serta penetapan indikator pencapaian program berdasarkan hasil social mapping dan rencana program yang telah disusun. Kemudahan dalam melakukan proses birokrasi juga dirasakan oleh pendamping lapangan yaitu aparat pemerintah Desa Pasanggrahan juga sangat mendukung dan terbuka kepada pihak perusahaan dan Human Initiative Jabar dalam membantu pelaksanaan program pemberdayaan ekonomi yang dilakukan.

Selain ketiga aspek diatas, sumber daya (resources) juga menjadi salah satu faktor yang mempengaruhi keberhasilan pelaksanaan CSR PT. Tirta Investama Subang. Menurut Solichin Abdul Wahab dalam M. Fitrah Wardiman (2015:16) sumber daya (resources) ini meliputi banyak komitmen seperti jumlah staf dan kualitas mutu, informasi yang diperlukan, penanggung jawab, serta berbagai fasilitas yang dibutuhkan dalam pelaksanaan program. Berdasarkan hasil penelitian, dalam pelaksanaanya PT. Tirta Investama Subang memiliki sumber daya yang mendukung untuk pelaksanaan program pemberdayaan ekonomi seperti sarana dan prasarana yang lengkap dalam kegiatan operasional bagi pendamping dan masyarakat dampingan, kemudian adanya komitmen yang tinggi dari pihak perusahaan, pendamping lapangan dan masyarakat dalam menjalankan program, serta adanya pembagian peran dan tugas yang jelas sebagai penanggungjawab dalam setiap kegiatan yang dilakukan. Namun dalam pelaksanaannya terkait sumber daya ini masih perlu ada yang ditingkatkan seperti diperlukannya tambahan pendamping lapangan untuk memaksimalkan pelaksanaan program, dilaksanakannya sosialisasi lanjutan terkait sosialisasi data rencana kerja kepada masyarakat sasaran agar rencana program yang disosialisasikan tersampaikan secara menyeluruh, diperlukannya penyampaian informasi yang menyeluruh kepada fasilitator baru yang akan melanjutkan tugas dan peran pendamping yang sudah resign, dan peningkatan kemampuan masyarakat dampingan terkait digital marketing melalui pelibatan generasi muda agar program pemberdayaan ekonomi yang dilaksanakan di Desa Pasanggrahan dapat maksimal.

\section{Harapan Informan dalam Pelaksanaan Corporate Social Responsibility PT. Tirta Investama Subang Dalam Memberdayakan Ekonomi Masyarakat Desa Pasanggrahan}

Berikut ini harapan - harapan dari informan sebagai bahan rekomendasi yang dapat ditindaklanjuti agar proses pelaksanaan program pemberdayaan ekonomi dapat berjalan lebih optimal, yaitu sebagai berikut:

1. Adanya Kegiatan Sharing Session

Sharing session ini merupakan kegiatan yang dapat dilakukan pada tahap perencanaan. Dalam kegiatan tersebut harapannya ada proses penyampaian historis program yang dilakukan oleh fasilitator lama kepada fasilitator baru terkait proses yang sudah dijalankan secara spesifik terutama hal-hal yang belum tercapai pada masa kerja fasilitator lama sehingga menjadi tugas yang harus dilanjutkan oleh fasiliatator baru. Melalui kegiatan sharing session harapannya fasilitator baru tidak hanya memahami program yang sudah dilaksanakan dari dokumen atau laporan saja, tetapi memperoleh 
penjelasan langsung dari pihak yang sudah berpengalaman dalam menjalankan program pemberdayaan ekonomi yang dilakukan oleh PT. Tirta Investama Subang. Selain itu jjuga menambah kesiapan fasilitator baru dalam menjalankan peran dan tugas baru di lapangan sehingga fasilitator bisa dan membangun strategi untuk melaksanakan program secara maksimal.

2. Adanya Sosialisasi Lanjutan Data Rencana Kerja

Proses sosialisasi data rencana kerja yang dilakukan oleh PT. Tirta Investama Subang disampaikan secara jelas kepada masyarakat. Hanya saja karena saat ini berada dalam situasi Covid-19, sehingga undangan masyarakat dilakukan pembatasan dan proses penyampaian informasi tidak tersampaikan secara menyeluruh kepada masyarakat sasaran. Oleh karena itu, salah satu alternatif yang bisa dilakukan yaitu diadakan sosialisasi lanjutan data rencana kerja melalui pemanfaatan teknologi informasi. Dengan adanya kegiatan sosialisasi lanjutan ini harapannya rencana program tersampaikan secara menyeluruh kepada masyarakat sasaran.

3. Adanya proses pelibatan generasi muda dalam mengelola Koperasi Pasgajaya

Perkembangan dan penambahan para pelaku UMKM di Desa Pasanggrahan harus diimbangi dengan pemasaran produk yang baik. Generasi muda merupakan kalangan yang cukup strategis dalam memasarkan produk UMKM, karena anak muda mampu berkreasi dan membuat sebuah inovasi serta akrab dengan teknologi digital. Kalangan milenial perlu didampingi untuk agar mau mengambil peran dalam usaha peningkatan ekonomi lokal Desa Pasanggrahan. Dengan adanya pelibataktifan generasi muda harapannya mampu memberikan kesempatan bagi anak muda untuk berperan dalam proses pemberdayaan ekonomi yang dilakukan dan proses pemasaran produk dapat dilakukan dengan maksimal.

4. Adanya penambahan jumlah sumber daya pendamping lapangan

Sumber daya yang memadai merupakan salah satu faktor pendukung keberhasilan pelaksanaan program. Maka dari itu, kinerja pendamping lapangan pun sangat menentukan dalam mensukseskan program yang dilaksanakan oleh PT. Tirta Investama Subang. Dalam pelaksanaannya, pendamping lapangan merasa perlu adanya tambahan pendamping lapangan mengingat cakupan area dalam program pemberdayaan ekonomi ini dilakukan di tiga wilayah yaitu Desa Darmaga, Desa Pasanggrahan dan Kampung Adat Banceuy dan sasaran dalam program pemberdayaan ekonomi yaitu masyarakat. Sehingga hal ini juga mempengaruhi kinerja pendamping lapangan dan beban tugas yang harus dilaksanakan.

\section{KESIMPULAN}

Berdasarkan hasil penelitian dapat disimpulkan bahwa PT. Tirta Investama Subang bersama Human Initiative Jabar sudah melaksanakan tahapan-tahapan pelaksanaan CSR nya dengan baik karena dalam setiap tahapan yang dilakukan sudah memenuhi aspek-aspek atau langkahlangkah yang harus dilakukan pada setiap tahapan pelaksanaan CSR. Adapun tahapan yang dilakukan oleh PT. Tirta Investama Subang bersama Human Initiative Jabar dalam melaksanakan CSR nya terdiri dari tahap perencanaan, tahap pelaksanaan dan tahap evaluasi lapangan. Pada tahap perencanaan, PT. Tirta Investama Subang melaksanakan tiga langkah utama yaitu Awareness Building yang diawali dari pemikiran pendiri AQUA, yaitu Bapak Tirto Utomo yang berprinsip 
bahwa bisnis harus berkontribusi pada pengembangan sosial masyarakat. Sehingga pihak perusahaan memiliki komitmen dan kesadaran yang tinggi untuk menjalankan tanggung jawab sosial perusahaan melalui program nya yang disebut "Aqua Lestari”. Selain itu, Awareness Building ini tidak hanya dilakukan di lingkungan perusahaan saja, tetapi juga dilakukan di lingkungan masyarakat melalui kegiatan Sosialisasi Data Rencana Kerja. Kemudian PT. Tirta Investama Subang bersama Human Initiative Jabar juga melakukan CSR Assessment melalui kegiatan social mapping untuk mengetahui informasi secara luas terkait masyarakat terutama pemetaan masalah, pemetaan potensi, pemetaan kebutuhan dan rekomendasi program yang sesuai dengan pioritas kebutuhan masyarakat dengan melibatakifkan masyarakat Desa Pasanggrahan dari seluruh kalangan masyarakat sehingga memberikan ruang bagi masyarakat dalam pengambilan keputusan dan perencanaan program yang akan dilaksanakan agar sesuai dengan kebutuhan masyarakat dan tepat sasaran dan yang terkahir PT. Tirta Investama Subang melakukan CSR Manual Building melalui pembuatan time line rencana dan Standar Operasional Prosedur (SOP) yang telah disepakati oleh komite perusahaan dan Human Initiative Jabar yang mengacu pada indikator yang ingin dicapai.

Pada tahap pelaksanaan PT. Tirta Investama Subang bersama Human Initiative Jabar melaksanakan sosialisasi untuk memperkenalkan kepada komponen perusahaan mengenai pelaksanaan tanggung jawab sosial perusahaan. Dalam hal ini, proses sosialisasi terkait pelaksanaan dan pentingnya tanggung jawab sosial perusahaan dilakukan oleh AQUA Group yang menaungi PT. Tirta Investama Subang melalui program "Aqua Lestari” yang terinternalisasi dalam seluruh proses bisnis perusahaan yang dilakukan melalui pelaksanaan berbagai program CSR dalam berbagai bidang. Kemudian pada tahap pelaksanaan, PT. Tirta Investama Subang bersama Human Initiative Jabar juga melaksanakan program yang sudah direncanakan dan disepakati bersama masyarakat dengan memberikan proses edukasi, advokasi, pemberian motivasi kepada masyarakat, dan membangun kerjasama dengan para stakeholder dan orang yang expert dalam bidangnya untuk memberikan kegiatan pelatihan sesuai rencana kerja.

Pada tahap evaluasi lapangan PT. Tirta Investama Subang bersama Human Initiative Jabar melaksanakan proses monitoring dan evaluasi, proses pelaporan dan audit. Evaluasi lapangan dilakukan secara berkala dan sesuai kesepakatan komite program antara pihak perusahaan dengan Human Initiative Jabar untuk memantau perkembangan atau capaian pelaksanaan program sesuai indikator yang telah ditentukan. Adapun proses pelaporan disampaikan sesuai dengan tahap dan jadwal program lengkap dengan perkembangan intervensi sosial yang dilakukan. Dalam proses pelaporan ini, pihak perusahaan menerima laporan dari Human Initiative Jabar berupa laporan harian, laporan kegiatan, laporan bulanan dan laporan tahunan sebagai dasar dan sumber informasi dalam pengambilan keputusan bagi pemilik kebijakan perusahaan. Kemudian dalam proses audit ini, PT. Tirta Investama Subang melakukan pengawasan secara langsung yang diwakili oleh CSR Supervisor dan Tim External Audit baik dari pihak perusahaan maupun dari Human Initiative Jabar. Pelaksanaan proses audit ini dilakukan secara rutin pada setiap kegiatan yang dilakukan atau satu bulan sekali dengan membuat mekanisme cek dan kontrol.

Dalam penelitian ini juga dapat disimpulkan bahwa faktor yang mempengaruhi keberhasilan dalam pelaksanaan CSR yang dijalankan oleh PT. Tirta Investama Subang bersama Human Initiative Jabar yaitu adanya proses komunikasi yang baik, adanya faktor disposisi dan dukungan faktor struktur birokrasi dimana kebijakan dan program "Aqua Lestari" yang diselenggarakan oleh PT. Tirta Investama Subang merupakan landasan dan pendukung dalam program pemberdayaan ekonomi yang dilakukan serta sumber daya (resources) yang mendukung namun masih perlu adanya beberapa aspek yang perlu ditingkatkan dan dapat dijadikan sebagai saran atau 
rekomendasi bagi pihak perusahaan dan Human Initiative Jabar dalam melaksanakan program pemberdayaan ekonomi di Desa Pasanggrahan.

\section{DAFTAR PUSTAKA}

Annual Report CSR PT. Tirta Investama Subang Tahun 2020

Dwi Kartini. 2009. Corporate Social Responsibility: Transformasi Konsep Sustainability Management dan Implementasi di Indonesia. Bandung: PT. Refika Aditama

Hendrik Budi Untung. 2008. Corporate Social Responsibility. Jakarta: Sinar Grafika
M. Fitrah Wardiman. 2015. Pelaksanaan Corporate Social Responsibility (CSR) PT. Surya Raya Lestari II Terbadap Pemberdayaan Ekonomi Masyarakat. STKS Bandung

Profil PT. Tirta Investama Subang

Profil Desa Pasanggrahan

Profil Koperasi Pasgajaya Abadi

Undang-Undang Nomor 40 Tahun 2007 Tentang Perseroan Terbatas

Yusuf Wibisono. 2007. Membedah Konsep dan Aplikasi CSR. Gresik: Fascho Publishing 